Article

\title{
Photosensitizer-Embedded Polyacrylonitrile Nanofibers as Antimicrobial Non-Woven Textile
}

\author{
Sarah L. Stanley ${ }^{1}$, Frank Scholle ${ }^{2}$, Jiadeng Zhu ${ }^{3}$, Yao Lu ${ }^{3}$, Xiangwu Zhang ${ }^{3}$, Xingci Situ ${ }^{1}$ \\ and Reza A. Ghiladi ${ }^{1}$ * \\ 1 Department of Chemistry, North Carolina State University, Raleigh, NC 27695-8204, USA; \\ slstan12@ncsu.edu (S.L.S.); xsitu1@gmail.com (X.S.) \\ 2 Department of Biological Sciences, North Carolina State University, Raleigh, NC 27695-7614, USA; \\ fscholl@ncsu.edu \\ 3 Fiber and Polymer Science Program, Department of Textile Engineering, Chemistry and Science, \\ North Carolina State University, Raleigh, NC 27695-8301, USA; jzhu14@ncsu.edu (J.Z.); \\ ylu14@ncsu.edu (Y.L.); xzhang13@ncsu.edu (X.Z.) \\ * Correspondence: reza_ghiladi@ncsu.edu; Tel.: +1-919-389-1716; Fax: +1-919-515-5079 \\ Academic Editor: Sheshanath V. Bhosale \\ Received: 16 March 2016; Accepted: 11 April 2016; Published: 20 April 2016
}

\begin{abstract}
Toward the objective of developing platform technologies for anti-infective materials based upon photodynamic inactivation, we employed electrospinning to prepare a non-woven textile comprised of polyacrylonitrile nanofibers embedded with a porphyrin-based cationic photosensitizer; termed PAN-Por ${ }^{(+)}$. Photosensitizer loading was determined to be $34.8 \mathrm{nmol} / \mathrm{mg}$ material; with thermostability to $300{ }^{\circ} \mathrm{C}$. Antibacterial efficacy was evaluated against four bacteria belonging to the ESKAPE family of pathogens (Staphylococcus aureus; vancomycin-resistant Enterococcus faecium; Acinetobacter baumannii; and Klebsiella pneumonia), as well as Escherichia coli. Our results demonstrated broad photodynamic inactivation of all bacterial strains studied upon illumination (30 min; $65 \pm 5 \mathrm{~mW} / \mathrm{cm}^{2} ; 400-700 \mathrm{~nm}$ ) by a minimum of $99.9996+\%$ (5.8 log units) regardless of taxonomic classification. PAN-Por ${ }^{(+)}$also inactivated human adenovirus-5 ( 99.8\% reduction in PFU/mL) and vesicular stomatitis virus ( $>7 \log$ units reduction in PFU $/ \mathrm{mL}$ ). When compared to cellulose-based materials employing this same photosensitizer; the higher levels of photodynamic inactivation achieved here with PAN-Por ${ }^{(+)}$are likely due to the combined effects of higher photosensitizer loading and a greater surface area imparted by the use of nanofibers. These results demonstrate the potential of photosensitizer-embedded polyacrylonitrile nanofibers to serve as scalable scaffolds for anti-infective or self-sterilizing materials against both bacteria and viruses when employing a photodynamic inactivation mode of action.
\end{abstract}

Keywords: photodynamic inactivation; singlet oxygen; antibacterial; antiviral; photobiocidal; polyacrylonitrile; photosensitizer; porphyrin

\section{Introduction}

According to the center for disease control's (CDC's) Healthcare-Associated Infections (HAI) Prevalence Survey, there were an estimated 722,000 HAIs in U.S. acute care hospitals in 2011, equivalent to $\sim 1$ out of every 25 inpatients having at least one health care-associated infection on any given day [1]. Approximately 75,000 deaths were attributed to these infections, or about $10 \%$ of the total HAIs. When one considers that these estimates of the national burden of health care-associated infections were limited to acute care hospitals, factoring in the magnitude of HAIs attributed to other settings (e.g., skilled nursing facilities, outpatient clinics, urgent care facilities) further highlights the scope and staggering cost of nosocomial infections. One of the main contributing factors to HAIs is the ability of pathogens such as bacteria, fungi, and viruses to adhere to, and survive on, surfaces that leads to 
their subsequent transmission to new hosts [2-5]. As an example, Staphylococcus aureus can survive for weeks to months under dry conditions on the cotton and polyester fabrics used in hospitals $[6,7]$. Though typically not a concern for healthy individuals, a second factor that contributes to HAIs is drug resistance, and five classes of antibiotic-resistant pathogens in particular have emerged as major public health threats: vancomycin-resistant enterococci (VRE), methicillin-resistant Staphylococcus aureus (MRSA), multidrug-resistant mycobacteria, Gram-negative bacteria, and fungi [8]. To combat these contributing factors to HAIs, more research into effective surface disinfection and alternative materials (fabrics, plastics or coatings) with antimicrobial properties capable of overcoming drug-resistance is needed. Moreover, food processing, packaging and service industries, waste water treatment, daycare facilities, and personal households are other areas where infectious agents are easily spread, but may be countered by an anti-infective coating.

In general terms, an ideal anti-infective surface necessitates a permanent or rechargeable anti-infective character, is harmless to the environment, operates in a user-independent manner, and effectively leads to the eradication of a broad scope of pathogens [9-11]. Several classes of antimicrobial agents are currently being investigated or are commercially available [12-21], yet have disadvantages such as the loss of antimicrobial activity by leaching of the biocide, consumption of the germicidal ability, environmentally hazardous agents, dependency on direct contact of the antimicrobial entity with the microorganism, and/or their efficacy is often limited to a single class of microbe (i.e., only bacteria or fungi). A promising area that circumvents many of these shortcomings while at the same time satisfying many of the aforementioned criteria of an ideal anti-infective material is antimicrobial photodynamic inactivation (aPDI) [22-26]. aPDI employs light, air, and a photosensitizer (PS) to generate primarily singlet oxygen $\left({ }^{1} \mathrm{O}_{2}\right)$ as the biocidal agent, and represents a complementary strategy for the treatment of microbial infections $[27,28]$. Advantages of materials-based aPDI include (i) employing singlet oxygen as the biocidal agent (which, given its short lifetime and decay to harmless oxygen as an end product [29] can be considered environmentally benign); (ii) multiple routes to PS incorporation, including the attachment of the PS through electrostatic interactions [30], encapsulation within a polymeric matrix [30-36], or direct attachment via a covalent bond (prevents leaching into the environment) [37-44]; (iii) the ability of the PS to potentially function in the absence of direct contact with the pathogen due to the diffusibility of singlet oxygen [40,45]; and (iv) of great importance with respect to nosocomial infections is that singlet oxygen or other photo-generated reactive oxygen species cause non-specific damage from which microbial resistance is unlikely to arise [27,46,47]. To this latter point, aPDI has been shown to possess broad-spectrum antibacterial [23,27,48-50], antiviral [31,51-53], antifungal [46,54-56], and antiparasitic [57,58] properties. Finally, as aPDI employs harmless white light [10], it has the advantage over ultraviolet-C (UVC) (as an example of another light-based sterilization technique), vaporized hydrogen peroxide, or chlorine dioxide in that it can function without the need for protecting people against the deleterious effects of the biocidal agent.

A number of materials based upon a photodynamic mode of action have been recently reported. These include: synthetic polymer materials (polyurethane, polystyrene, polycaprolactone and polyamide-6) with encapsulated photosensitizers (e.g., free-base or zinc tetraphenylporphyrin, zinc phthalocyanine, cationic 5,10,15,20-tetrakis(1-methylpyridinium-4-yl)porphyrin (TMPyP)) that exhibit photobactericidal (E. coli) and photovirucidal (against non-enveloped polyomavirus and enveloped baculovirus) efficacy [30-36], as well as natural polymer materials based on cellulose nanocrystals $\left(\right.$ Por $^{(+)}$-CNCs [37,38,59]), cellulose fibers $\left(\right.$Por $^{(+)}$-paper [39]), or cotton fabrics [42,44] that possess broad anti-infective efficacy against both bacteria (e.g., Staphylococcus aureus, vancomycin-resistant Enterococcus faecium, Acinetobacter baumannii, Pseudomonas aeruginosa, and Klebsiella pneumonia) and viruses (e.g., dengue-1, influenza A, and human adenovirus-5). However, further studies regarding the design, scope, and potential applications of these materials remain. These include: (i) better defining the scope of antibacterial activity for synthetic nanofiber materials as their photobactericidal studies were primarily limited to $E$. coli, (ii) direct comparison of synthetic $v$ s. natural polymers as scaffolds for photoactive materials, and (iii) gaining additional insight into whether more facile photosensitizer 
embedding/encapsulation strategies are sufficient for material design, or are covalent approaches necessary for maximum anti-infective efficacy.

To begin to address these areas systematically, the objective of the present study was to prepare polyacrylonitrile nanofibers embedded with a photosensitizer via electrospinning, and to study the anti-infective properties of the resulting non-woven textile, termed PAN-Por ${ }^{(+)}$, against both Gram-positive and Gram-negative bacteria of the ESKAPE family of pathogens [60], as well as to extend these photoinactivation studies against viruses (ESKAPE $=$ acronym for the most common nosocomial infectious agents, Enterococcifaecium, Staphylococcusaureus, Klebsiellapneumoniae, Acinetobacterbaumannii, Pseudomonasaeruginosa, and Enterobacter species). The strategy employed enables the comparison of the antimicrobial efficacy of PAN-Por ${ }^{(+)}$to similar cellulose-based counterparts $\left(\mathrm{Por}^{(+)}-\mathrm{CNCs}[37,38]\right.$ and $\mathrm{Por}^{(+)}$-paper [39]) that our lab has recently studied. As we are employing the same porphyrin-based cationic photosensitizer (i.e., $\operatorname{Por}^{(+)}$), such a comparison will enable us to better understand how the use of synthetic (polyacrylonitrile) nanofibers vs. natural (cellulose) fibers impacts the design of antimicrobial materials, as well as enable a direct comparison of the more facile embedded photosensitizer approach used in the preparation of PAN-Por ${ }^{(+)}$against the more synthetically challenging covalent attachment method used in $\mathrm{Por}^{(+)}-\mathrm{CNC}$ and $\operatorname{Por}^{(+)}$-paper.

\section{Results and Discussion}

\subsection{Electrospinning and Characterization of PAN-Por ${ }^{(+)}$Nanofibers}

\subsubsection{Scanning Electron Microscopy (SEM) of PAN-Por ${ }^{(+)}$}

The preparation of PAN-Por ${ }^{(+)}$nanofibers was accomplished by thoroughly mixing precursor $\operatorname{Por}^{(+)}$and PAN prior to electrospinning. Application of a high voltage and collection on an aluminum foil target yielded the green PAN-Por ${ }^{(+)}$nanofiber material as shown in Figure 1. Characterization by scanning electron microscopy (SEM) of both the PAN-Por ${ }^{(+)}$nanofibers as well as the photosensitizer-free (control) PAN nanofibers (Figure S1) revealed that both materials were highly similar overall, consisting of randomly arranged fibers with an average diameter of $\sim 175 \mathrm{~nm}$. The high-resolution SEM images (Figure 1 and Figure S1, inserts) demonstrate that the nanofibers of PAN-Por ${ }^{(+)}$and PAN have surfaces of equivalent smoothness, suggesting that presence of the cationic Por $^{(+)}$photosensitizer does not impact the morphology of the resulting nanofibers.

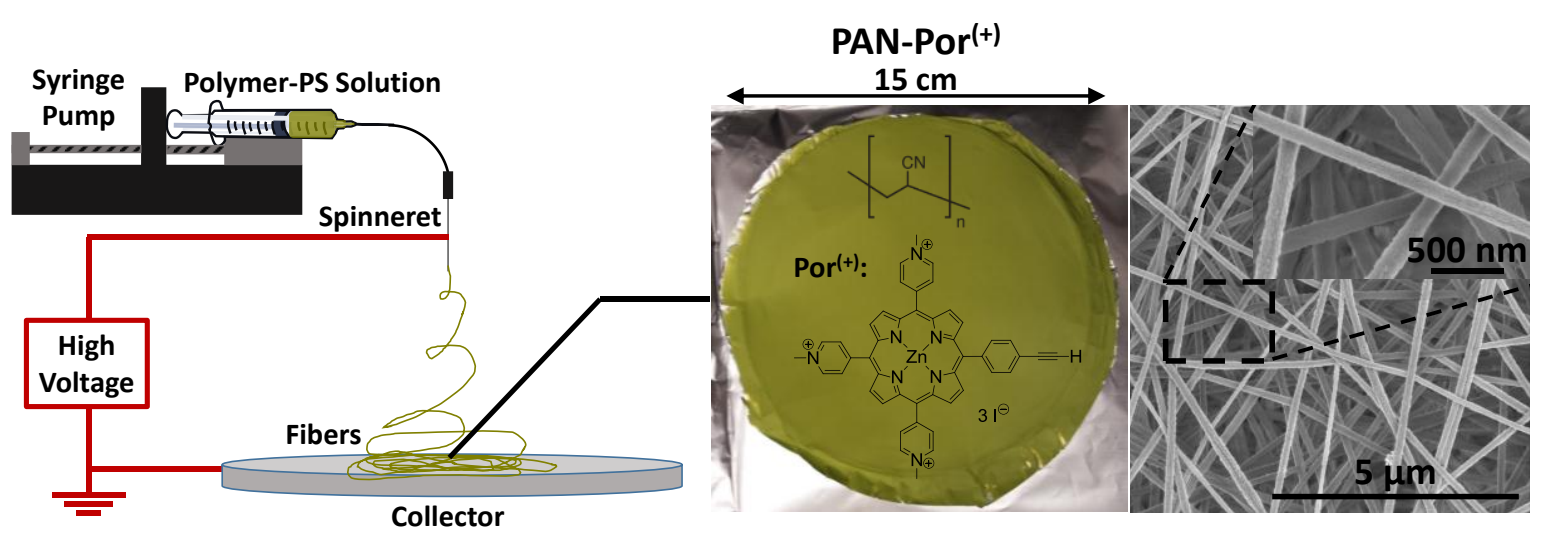

Figure 1. Electrospinning schematic (left), PAN-Por ${ }^{(+)}$(middle), and scanning electron microscopy (SEM) images (right).

\subsubsection{Determination of Photosensitizer Loading in PAN-Por ${ }^{(+)}$}

Prior to the determination of photosensitizer loading and subsequent antimicrobial studies, each sample of PAN-Por ${ }^{(+)}$was washed, thereby removing adventitiously bound $\mathrm{Por}^{(+)}$to a concentration 
of less than $19 \mathrm{nM}$ as determined by UV-visible spectroscopy (vide infra). To determine the extent of porphyrin loading, washed PAN-Por ${ }^{(+)}$was dissolved in dimethylformamide (DMF), solubilizing both the PAN nanofibers and the Por $^{(+)}$photosensitizer, thereby enabling the photosensitizer content to be determined by UV-visible spectroscopy to be $34.8 \pm 0.1 \mathrm{nmol} \mathrm{Por}^{(+)} / \mathrm{mg}$ PAN-Por ${ }^{(+)}$, approximately three-fold higher than $\operatorname{Por}^{(+)}$-paper (12.4 $\mathrm{nmol} \mathrm{Por}^{(+)} / \mathrm{mg}$ material [39]), but less than the $160 \mathrm{nmol} \mathrm{Por}{ }^{(+)} / \mathrm{mg}$ material in Por $^{(+)}$-CNCs [37]. The value of $34.8 \pm 0.1 \mathrm{nmol} \mathrm{Por}^{(+)} / \mathrm{mg}$ PAN-Por ${ }^{(+)}$represents $3.9 \%$ of the overall mass of PAN-Por ${ }^{(+)}$nanofibers (based on the triiodide salt of $\left.\operatorname{Por}^{(+)}[37,61]\right)$, and suggests that of the $10 \mathrm{wt} \%$ with respect to the mass of PAN that was used in the electrospinning of PAN-Por ${ }^{(+)}$, that $6.1 \%$ of the $\mathrm{Por}^{(+)}$was adventitiously bound and removed during the washing procedure.

\subsubsection{Thermal Gravimetric Analysis (TGA) of PAN-Por ${ }^{(+)}$}

Thermal gravimetric analysis was performed on the unmodified PAN mother fibers and PAN-Por ${ }^{(+)}$to gain an understanding of the thermal stability of these materials (Figure S2). Overall, both unmodified PAN and PAN-Por ${ }^{(+)}$nanofibers exhibited virtually identical thermostability, with negligible weight losses of $1.1 \%$ and $0.5 \%$, respectively, up to $300{ }^{\circ} \mathrm{C}$, a result that was not wholly unexpected: while the $\operatorname{Por}^{(+)}$photosensitizer has been shown to lose $30 \%$ of its mass between 180 and $300{ }^{\circ} \mathrm{C}$ (and ultimately ca. $42.5 \%$ loss at $330{ }^{\circ} \mathrm{C}$ [37]), the level of Por $^{(+)}$photosensitizer loading (34.8 nmol Por $^{(+)} / \mathrm{mg}$ PAN-Por ${ }^{(+)}$nanofibers, vide supra) represents only $3.9 \%$ of the overall mass of PAN-Por ${ }^{(+)}$nanofibers. As such, a 1.2\% overall mass loss (at most) was expected based on the known behavior of $\operatorname{Por}^{(+)}$, compared with the $0.5 \%$ loss observed, the difference of which is likely due to the error inherent in TGA measurements, although we cannot conclusively rule out that the nanofibers themselves inhibit thermal decomposition of $\operatorname{Por}^{(+)}$. By way of comparison to the cellulose based analogs, $\operatorname{Por}^{(+)}$-paper displayed a similar thermostability (no significant mass reduction was observed until $290{ }^{\circ} \mathrm{C}[39]$ ), whereas Por $^{(+)}$-CNCs afforded a material with a much greater weight loss of $\sim 20 \%$ observed at $300^{\circ} \mathrm{C}[37]$.

\subsection{Antibacterial Photodynamic Inactivation Studies}

\subsubsection{In vitro aPDI Studies against Gram-Positive and Gram-Negative Bacteria}

In vitro aPDI studies employing PAN-Por ${ }^{(+)}$were performed under fixed illumination conditions (30 $\mathrm{min}, 400-700 \mathrm{~nm}, 65 \pm 5 \mathrm{~mW} / \mathrm{cm}^{2}$ ) to enable comparisons with previous studies that employed the identical photosensitizer covalently appended to cellulose nanocrystals (as $\operatorname{Por}^{(+)}$-CNCs $[37,38]$ ) and cellulose fibers (as Por ${ }^{(+)}$-paper [39]). The two Gram-positive bacteria, S. aureus ATCC-2913 and the vancomycin-resistant E. faecium (VRE) strain ATCC-2320, were found to be highly susceptible to photodynamic inactivation with PAN-Por ${ }^{(+)}$: upon illumination, S. aureus was fully inactivated to the detection limit $(>99.9999+\%, 6 \log$ units, $p<0.005$; Figure $2 \mathrm{~A}$, red), and vancomycin-resistant E. faecium (ATCC-2320) was inactivated by $99.9998 \%$ ( 5.9 log units, $p<0.005$; Figure 2A, red). By contrast, all bacteria exhibited $100 \%$ survival on the unmodified PAN (PS-free control) under the same illumination conditions (see Figure S3 for representative data against K. pneumonia), demonstrating the requirement of the photosensitizer for bacteria inactivation. Although $<1 \log$ unit, the dark controls employing PAN-Por ${ }^{(+)}$also exhibited inactivation (Figure 2, maroon), likely due to the photodynamic production of singlet oxygen by the material even when minimizing the ambient room light during the assay, although we cannot conclusively rule out a slight dark toxicity of the material. Photodynamic inactivation under dark control conditions has been noted previously for $\mathrm{Por}^{(+)}$-paper [39], but could be circumvented in that study by using a darkroom red light that emitted at wavelengths where the photosensitizer did not absorb well. Here, we suggest that the $\sim 3 \times$ higher loading of the PS in PAN-Por ${ }^{(+)}$when compared with Por $^{(+)}$-paper leads to this material having a very high sensitivity to even such minimal light conditions employed during the serial dilution and other workup steps of the assay. By way of comparison for S. aureus, PAN-Por ${ }^{(+)}$achieved a comparable level of inactivation 
as Por $^{(+)}$-CNC ( 6 log units, [37,38]), and was superior to $\operatorname{Por}^{(+)}$-paper ( 5 log units, [39]). Moreover, while not previously tested against Por $^{(+)}-C N C s$, against the E. faecium strain PAN-Por ${ }^{(+)}$also achieved a far higher level of inactivation than Por $^{(+)}$-paper (4 log unit CFU reduction, [39]).

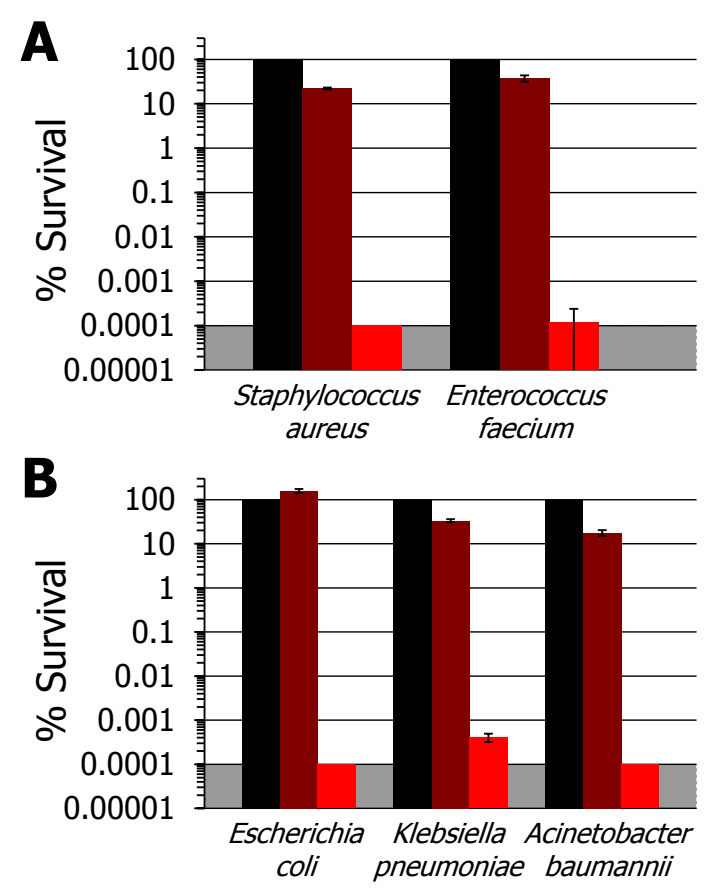

Figure 2. Photodynamic inactivation studies employing PAN-Por ${ }^{(+)}$. (A) Gram-positive species: methicillin-susceptible S. aureus (MSSA) ATCC-2913 and the vancomycin-resistant E. faecium (VRE) ATCC-2320 strain. (B) Gram-negative species: E. coli BL21-(De3)pLysS, K. pneumoniae ATCC-2146, and A. baumannii ATCC-19606. For both panels, displayed are the material-free (cells-only) dark control set to $100 \%$ (black), as well as the dark control of PAN-Por ${ }^{(+)}$(maroon) and the illuminated PAN-Por ${ }^{(+)}$ (red) studies, both as the percent survival of the material-free (cells-only) dark control. For all bacteria, the illumination conditions were as follows: $30 \mathrm{~min}, 400-700 \mathrm{~nm}, 65 \pm 5 \mathrm{~mW} / \mathrm{cm}^{2}$ (total fluence of $118 \mathrm{~J} / \mathrm{cm}^{2}$ ). As the plating technique employed to determine \% survival did not allow for detection of survival rates of $<0.0001 \%$, data points below the detection limit were set to $0.0001 \%$ survival for graphing purposes and are indicated by the grey shaded area. In the cases where error bars cannot be visualized, the error bars themselves were smaller than the marker employed in the plot.

When explored against Gram-negative bacteria, PAN-Por ${ }^{(+)}$showed virtually identical inactivation efficacy (Figure 2B) when compared to the Gram-positive strains above under the same illumination conditions. Generally speaking, this was unexpected as the additional outer membrane of highly impermeable lipopolysaccharides present in Gram-negative bacteria makes them more resistant to photodynamic inactivation than Gram-positive species [62], but we have noted this previously for Por $^{(+)}$-paper (but not for Por ${ }^{(+)}$-CNCs) [39]. Specifically, we observed here that both Escherichia coli BL21-(De3)pLysS and Acinetobacter baumannii ATCC-19606 were fully inactivated to the detection limit (>99.9999+\%, 6 log units, $p<0.005$; Figure 2B, red), and the multi-drug resistant NDM-1-producing K. pneumoniae clinical isolate ATCC-2146 was inactivated to $99.9996+\%$ reduction $(\sim 5.8 \log$ units; $p<0.005)$. By way of comparison, PAN-Por ${ }^{(+)}$was able to achieve a modestly improved level of inactivation for Acinetobacter baumannii ATCC-19606 than either Por ${ }^{(+)}$-paper ( 5 log units [39]) or Por ${ }^{(+)}-C N C s$ (5.5 log units [38]), and was significantly superior against the K. pneumoniae clinical isolate ATCC-2146 than Por $^{(+)}$-paper (4.5 log units [39]). Even more impressively, PAN-Por ${ }^{(+)}$was far more effective against E. coli than Por $^{(+)}$-CNCs (1.8 log units reduction [37]). Note that neither K. pneumoniae clinical isolate ATCC-2146 nor E. coli were studied with Por $^{(+)}-$CNCs or $\operatorname{Por}^{(+)}$-paper, respectively, thereby preventing these comparisons. 
Finally, the effects of extended photobleaching were examined by pre-illuminating PAN-Por ${ }^{(+)}$ continuously for $8 \mathrm{~h}$ under identical illumination conditions $\left(400-700 \mathrm{~nm}, 65 \pm 5 \mathrm{~mW} / \mathrm{cm}^{2}\right)$, followed by repetition of the K. pneumoniae trial employing this pre-illuminated ("photo-aged") paper. Inactivation to $99.998 \%$ ( $5 \log$ units, $p<0.005)$ was observed (Figure S4), suggesting the material has excellent robustness with respect to photobleaching over the time period examined.

Taken together, the results demonstrate that PAN-Por ${ }^{(+)}$was able to achieve a comparable or superior level of photodynamic inactivation against the Gram-positive and Gram-negative bacteria examined here when compared with $\operatorname{Por}^{(+)}$-paper or $\operatorname{Por}^{(+)}-\mathrm{CNCs}$, while at the same time has the advantage in that it avoids the necessity of the tedious covalent attachment of the photosensitizer to the polymeric cellulose scaffold employed in those other materials. Based on the results, we surmise that the higher efficacy of PAN-Por ${ }^{(+)}$is likely due to two factors: (i) the $\sim 3 \times$ higher loading of the Por ${ }^{(+)}$ PS in PAN-Por ${ }^{(+)}$when compared with Por $^{(+)}$-paper likely leads to a higher production of bactericidal singlet oxygen (or other ROS), and (ii) the use of nanofibers in PAN-Por ${ }^{(+)}$generates a material with a greater surface area than the 10-50 $\mu \mathrm{m}$ diameter cellulose fibers [63] that are typical for materials such as Por $^{(+)}$-paper. Overall, our results against both Gram-positive and Gram-negative bacteria are particularly noteworthy in the context of 'ESKAPE' pathogens $[39,60]$ given the broad, detection-limit photoinactivation efficacy of PAN-Por ${ }^{(+)}$against the bacterial strains examined here regardless of their taxonomic classification.

\subsubsection{Solution Studies with Por $^{(+)}$}

UV-visible spectroscopic analysis of the washed PAN-Por ${ }^{(+)}$revealed that the washing procedure removed adventitiously bound $\operatorname{Por}^{(+)}$to a concentration of less than $19 \mathrm{nM}$. Although minor, the question arises as to whether even such a low level $(\leqslant 19 \mathrm{nM})$ of adventitiously bound photosensitizer would photoinactivate bacteria. Thus, a solution study was performed with $50 \mathrm{nM}$ Por $^{(+)}$, a higher concentration than present in the washed material, using the multi-drug resistant NDM-1-producing K. pneumoniae clinical isolate ATCC-2146 as our model organism under fixed illumination conditions (30 $\mathrm{min}, 400-700 \mathrm{~nm}, 65 \pm 5 \mathrm{~mW} / \mathrm{cm}^{2}$ ). Gratifyingly, with $100 \%$ cell survival noted for all conditions studied, no statistically significant inactivation of K. pneumoniae was observed (Figure 3), and the results of the solution study confirm that the results of our materials-based antimicrobial studies (vide supra) were due to embedded photosensitizer only, and not a solution-derived result from adventitiously bound photosensitizer at $\leqslant 19 \mathrm{nM}$. Additionally, it is important to note that solution studies with the structurally-related benchmark photosensitizer TMPyP [meso-tetrakis(1-methylpyridinium-4-yl)porphyrin] have shown no significant (i.e., <0.5 log unit inactivation) photoinactivation of any of the bacteria studied here at $100 \mathrm{nM}$ photosensitizer concentration (specifically Figure S4 in reference [50] and Figure 2.4A in reference [59]).

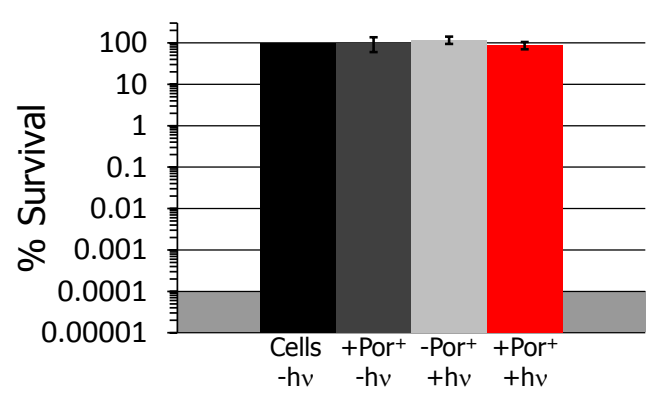

Figure 3. Photodynamic inactivation of Klebsiella pneumoniae using $50 \mathrm{nM} \mathrm{Por}^{(+)}$demonstrating that this photosensitizer (PS) concentration was unable to photoinactivate the bacterium. Displayed are the dark PS-free (cells-only) control set to $100 \%$ (black), the \% survival of the dark control of Por $^{(+)}$as a percent of the dark PS-free control (dark grey), the illuminated PS-free control as a percent of the dark PS-free control (light grey), and the illuminated $\operatorname{Por}^{(+)}$as a percent of the dark PS-free control (red). The illumination conditions and error bar visualizations were as described in Figure 2. 


\subsection{Antiviral Photodynamic Inactivation Studies}

PAN-Por ${ }^{(+)}$was examined for its antiviral PDI activity against two viruses: the non-enveloped human adenovirus-5 (HAd-5; Figure 4A) and enveloped vesicular stomatitis virus (VSV; Figure 4B). No inactivation of either virus was seen in the absence of material (material-free control) for either illuminated or non-illuminated conditions. In the presence of electrospun polyacrylonitrile nanofibers (PS-free PAN control), no statistically significant inactivation of either virus was observed under non-illuminated conditions, nor was any observed for HAd-5 upon illumination; only a minor $<1$ log unit reduction in PFU / $\mathrm{mL}$ was observed for VSV in the presence of illuminated PAN. Notably, however, upon illumination (30 $\mathrm{min}, 400-700 \mathrm{~nm}, 65 \pm 5 \mathrm{~mW} / \mathrm{cm}^{2}$ ) in the presence of PAN-Por ${ }^{(+)}$, human adenovirus-5 was inactivated to $\sim 99.8 \%$ reduction in PFU $/ \mathrm{mL}(\sim 2.9 \log$ units; $p<0.01$, Figure $4 \mathrm{~A})$, and represents approximately an order of magnitude improvement when compared to the results obtained for Por $^{(+)}$-paper ( $99 \%$ reduction in FFU/mL, 2 log units [39]). Even more impressive were the results obtained for vesicular stomatitis virus: inactivation of the virus exceeding $>7 \log$ units reduction in $\mathrm{PFU} / \mathrm{mL}$ was noted upon illumination for PAN-Por ${ }^{(+)}$(Figure 4B). We surmise that the difference in inactivation efficacy between these two viruses is likely due to the nature of the virus itself with respect to the viral envelope: the protein-based capsids of non-enveloped viruses may be more resistant to photosensitization than the lipid-bilayer-enclosed enveloped viruses, an observation that we noted previously in our studies with Por $^{(+)}$-paper [39], and that others have noted as well [51,64,65]. As was noted for the antibacterial studies, no statistically significant reduction for either virus was noted in the presence of PAN-Por ${ }^{(+)}$under non-illuminated conditions, again demonstrating the requirement of the photosensitizer for significant virus inactivation. Finally, as was also noted for the antibacterial studies, the improved efficacy of PAN-Por ${ }^{(+)}$when compared to Por $^{(+)}$-paper is likely due to the combined effects of higher photosensitizer loading and a potentially greater surface area due to the use of nanofibers (PAN) over the larger cellulose fibers.
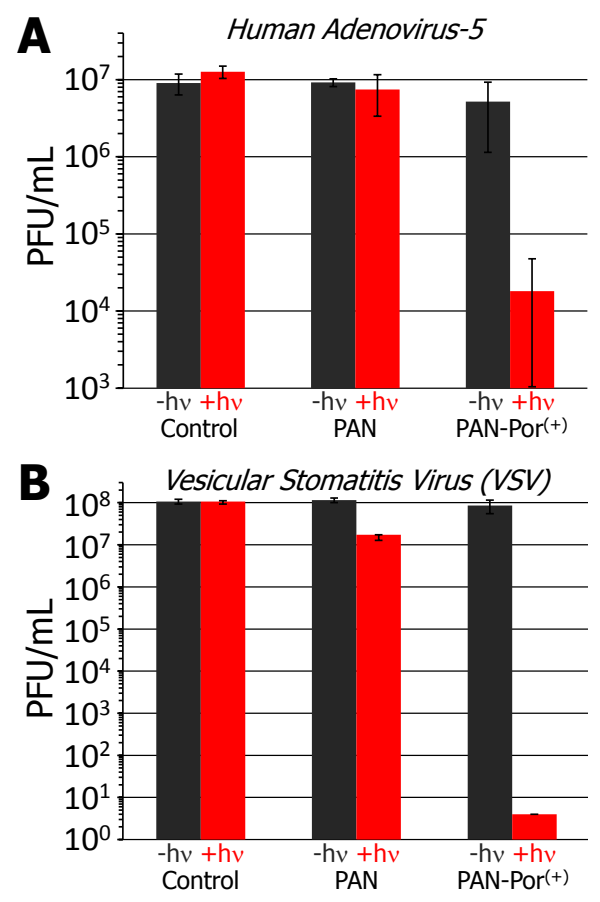

Figure 4. Antiviral photodynamic inactivation studies employing PAN-Por ${ }^{(+)}$against (A) human adenovirus-5 (HAd-5) and (B) vesicular stomatitis virus (VSV). The black and red bars represent the number of PFU/mL of the non-illuminated (dark) and illuminated conditions, respectively, for the material-free (control), photosensitizer-free (PAN only) control, and PAN-Por ${ }^{(+)}$studies. The illumination conditions and error bar visualizations were as described in Figure 2. 


\section{Experimental Section}

\subsection{Materials and Methods}

Buffer salts were purchased from Fisher Scientific (Pittsburgh, PA, USA), Nutrient Broth \#234000 was obtained from BD Difco (Franklin Lakes, NJ, USA), LB broth Miller from EMD Chemicals (Billerica, MA, USA), and Tryptic Soy Broth from Teknova (Hollister, CA, USA). Unless otherwise specified, all other chemicals were obtained from commercial sources in reagent grade purity or better. Deionized water was used for all media and buffers. UV-visible absorption measurements were performed on a Varian Cary 50 Bio instrument or a Genesys 10 UV scanning spectrophotometer from Thermo Electron Corp (Waltham, MA, USA) for single wavelength measurements. The photosensitizer Por ${ }^{(+)}$was synthesized as described previously [37,38,59]. Field-emission scanning electron microscopy (FE-SEM, FEI Verios 460L, Hillsboro, OR, USA) was performed at an acceleration voltage of $2 \mathrm{kV}$ to observe the morphology of the obtained materials. Thermal gravimetric analysis (TGA) was carried out on a TA instrument TGAQ50 (New Castle, DE, USA) ramping $8{ }^{\circ} \mathrm{C} /$ min under $\mathrm{N}_{2}$ purging.

\subsection{Electrospinning of PAN-Por ${ }^{(+)}$}

Polyacrylonitrile (PAN, $\left.\mathrm{M}_{\mathrm{W}}=150,000\right)$ and $N, N$-dimethylformamide (DMF) were purchased from Sigma-Aldrich (St. Louis, MO, USA) and used as received. The solution was prepared by firstly dissolving PAN powder into DMF solvent with a weight percentage of $5 \mathrm{wt} \%$. The PAN/DMF solution was stirred for over $24 \mathrm{~h}$, followed by the addition of cationic porphyrin $(1130 \mathrm{~g} / \mathrm{mol})$. The mass of cationic porphyrin was $10 \mathrm{wt} \%$ with respect to the mass of PAN. The solution was further stirred for $24 \mathrm{~h}$ prior to electrospinning in an apparatus that employed a Gamma ES40P-20 $\mathrm{W} /$ DAM variable high voltage $(15 \mathrm{kV})$ power supply. The flow rate applied was $0.75 \mathrm{~mL} / \mathrm{h}$. The needle-to-collector distance was set at $15 \mathrm{~cm}$ and electrospun fibers were collected on an aluminum foil. Prior to characterization and aPDI testing, the material was subjected to the following washing procedure: a sample of PAN-Por ${ }^{(+)}(\sim 1 \mathrm{mg})$ was placed in a 24-well plate, and a minimum of $2 \mathrm{~mL}$ deionized water was added by pipet. Agitation (swirling by hand or by pipet) proceeded for $30 \mathrm{~s}$, followed by removal of the solution. These steps were repeated for a total of eight iterations. Using this procedure, adventitiously bound $\operatorname{Por}^{(+)}$was decreased to a concentration of less than $19 \mathrm{nM}$ as determined by UV-visible spectroscopy.

\subsection{Determination of Porphyrin Loading}

Approximately $9 \mathrm{mg}$ of dry, washed textile was dissolved in $4 \mathrm{~mL}$ dimethylformamide and $6 \mathrm{~mL}$ deionized water, thereby fully solubilizing the $\operatorname{Por}^{(+)}$photosensitizer. The resulting solution was syringe filtered $(0.22 \mu \mathrm{m})$ to remove any trace of undissolved PAN nanofibers, diluted 1:6 with deionized water, and the concentration of the Por $^{(+)}$was determined by UV-visible spectroscopy using $\varepsilon_{\text {Soret }}=195,000 \mathrm{M}^{-1} \cdot \mathrm{cm}^{-1}[38,59]$.

\subsection{Cell culture}

Bacteria were cultured at $37^{\circ} \mathrm{C}$ in $5 \mathrm{~mL}$ culture tubes on an orbital shaker at $500 \mathrm{RPM}$. The following growth conditions were employed: methicillin susceptible Staphylococcus aureus 2913 was cultured without antibiotics in tryptic soy broth; vancomycin resistant Enterococcus faecium (ATCC-2320) was cultured with $50 \mu \mathrm{g} / \mathrm{mL}$ ampicillin in DB Difco Bacto Brain Heart Infusion 237500; Escherichia coli BL21-(De3)pLysS (Stratagene, San Diego, CA, USA) was grown in Miller LB media with $100 \mu \mathrm{g} / \mathrm{mL}$ ampicillin; Acinetobacter baumannii (ATCC-19606) was grown in Miller LB media without antibiotics. Klebsiella pneumoniae (ATCC-2146) was cultured with $100 \mu \mathrm{g} / \mathrm{mL}$ ampicillin in DB Difco Nutrient broth \#234000. A Genesys $10 \mathrm{UV}$ scanning spectrophotometer was employed to spectrophotometrically follow the growth of each bacterium to a concentration of $1-4 \times 10^{8} \mathrm{CFU} / \mathrm{mL}$, after which the bacteria were pelleted (15 $\mathrm{min}, \sim 4150 \mathrm{~g}$ ) by centrifugation, and the supernatant was removed via decantation. 
The bacteria were then resuspended in broth media $(5 \mathrm{~mL})$ and diluted to $\sim 10^{8} \mathrm{CFU} / \mathrm{mL}$ (determined spectrophotometrically).

\subsection{Viral Propagation}

Vero cells were employed to propagate (and titer by plaque assay) vesicular stomatitis virus (VSV) NJ strain. The human lung carcinoma cell line A549 was used to propagate and titer human adenovirus-5 (HAd-5). Plaques were visualized by crystal violet staining.

\subsection{Photodynamic Inactivation Assay}

A LumaCare USA model LC122 PDT non-coherent light source was employed for all antimicrobial photodynamic inactivation studies. The lamp was equipped with an OSRAM 64653 HLX Xenophot bulb (250 W, $24 \mathrm{~V})$, and employed a LUM V (400-700 $\mathrm{nm}$ band pass filter) fiber optic probe with a $\sim 95 \pm 3 \%$ average transmittance $\left(T_{\text {avg }}\right.$ ). An Orphir Optronics Ltd (Jerusalem, Israel) Orion power meter was used to determine the fluence rate of the LC122. At a minimum, experiments were performed in triplicate, and their statistical significance was determined using an unpaired Student's two-tailed $t$-test.

\subsubsection{Bacteria}

Sterile, flat-bottom 24-well plates (BD Falcon) were prepared with PAN-Por ${ }^{(+)}$cut to precisely fit the well bottom $(\sim 1 \mathrm{~cm}$ diam.) using a custom holepunch. Aliquots $(100 \mu \mathrm{L})$ of cell culture were transferred to each well and subjected to visible $\left(400-700 \mathrm{~nm}, 65 \pm 5 \mathrm{~mW} / \mathrm{cm}^{2}\right.$ fluence rate) light illumination for 5-60 min. Studies were repeated as described with PAN (PS-free material control), and in the absence of material (cells-only control), under both illuminated and non-illuminated (dark) conditions. After the illumination period, each well was serially diluted 1:10 five times. From each dilution, $10 \mu \mathrm{L}$ aliquots, from the undiluted well and from the dark control, were all separately plated and incubated at $37^{\circ} \mathrm{C}$ in the dark. Square agar plates (gridded six column), prepared without antibiotics and utilizing the appropriate growth media, were employed for each bacterium. The survival rate was calculated by dividing the $\mathrm{CFU} / \mathrm{mL}$ of the illuminated solution by the $\mathrm{CFU} / \mathrm{mL}$ of the dark control. As the plating technique employed a $10 \mu \mathrm{L}$ aliquot from the $1 \mathrm{~mL}$ undiluted well, the minimum detection limit was determined to be $100 \mathrm{CFU} / \mathrm{mL}$. Owing to variations in the starter culture concentrations spanning $1-4 \times 10^{8} \mathrm{CFU} / \mathrm{mL}$, a corresponding variation of the detection limit resulted from 0.001 to $0.0001 \%$. Illuminated samples of PAN without the photosensitizer served as the light control, whereas samples with PAN-Por ${ }^{(+)}$that were kept in the dark served as the dark control.

\subsubsection{Vesicular stomatitis virus}

There were $25 \mu \mathrm{L}$ of a VSV stock $\left(5 \times 10^{8}\right.$ plaque forming units $\left.(\mathrm{PFU}) / \mathrm{mL}\right)$ added to either empty well (control), PAN, or PAN-Por ${ }^{(+)}$in wells of a 96-well plate in the dark. The plates were subjected to visible $(400-700 \mathrm{~nm})$ light illumination for $30 \mathrm{~min}$ with a fluence of $65 \pm 5 \mathrm{~mW} / \mathrm{cm}^{2}$ for the aPDI assay, or were kept in the dark for the control experiments. Treatments were performed in biological triplicates. After illumination, $100 \mu \mathrm{L}$ of minimum essential medium (MEM) supplemented with $1 \%$ FBS, $10 \mathrm{mM}$ HEPES and antibiotics were added to wash remaining viruses off the textiles. Viruses were subsequently titered by serial dilution (10-fold) using Vero cells in 12 -well plates at $37^{\circ} \mathrm{C}$. VSV concentration (detection limit of $40 \mathrm{PFU} / \mathrm{mL}$ ) was determined by plaque assay. Crystal violet staining was employed to visualize the plaques $48 \mathrm{~h}$ after infection. For titer determination where VSV was detected, the diluted wells that contained between 10 and 30 plaques were counted. 


\subsubsection{Human adenovirus-5}

There were $25 \mu \mathrm{L}$ of a human adenovirus 5 stock $\left(4.5 \times 10^{7} \mathrm{PFU} / \mathrm{mL}\right)$ added to either empty well (control), PAN or PAN-Por ${ }^{(+)}$in wells of a 96 well plate in the dark. The plates were subjected to visible $(400-700 \mathrm{~nm})$ light illumination for $30 \mathrm{~min}$ with a fluence of $65 \pm 5 \mathrm{~mW} / \mathrm{cm}^{2}$ for the aPDI assay, or were kept in the dark for the control experiments. Treatments were performed in biological triplicates. After illumination, $100 \mu \mathrm{L}$ of DMEM supplemented with $10 \%$ FBS and antibiotics were added to wash remaining viruses off the textiles. Viruses were subsequently titered by serial dilution (10-fold) using A549 cells in 12-well plates at $37^{\circ} \mathrm{C}$. Plaques were detected by crystal violet staining $120 \mathrm{~h}$ after infection. For titer determination where HAd-5 was detected, the diluted wells that contained between 10-30 plaques were counted.

\section{Conclusions}

The antimicrobial efficacy of PAN-Por ${ }^{(+)}$was explored against taxonomically diverse bacteria, focusing on E. coli and the ESKAPE pathogens S. aureus, E. faecium, A. baumannii, and K. pneumoniae, as well as against viruses, including the non-enveloped human adenovirus- 5 and the enveloped vesicular stomatitis virus. Our results demonstrated that PAN-Por ${ }^{(+)}$possesses broad antibacterial efficacy, with equivalent levels of inactivation being observed regardless of the bacterial strain tested, and at levels that exceeded $\operatorname{Por}^{(+)}$-paper or $\operatorname{Por}^{(+)}-\mathrm{CNCs}$, the two cellulose-based materials employing the same photosensitizer via a covalent linkage to the polymer scaffold. PAN-Por ${ }^{(+)}$also exhibited improved antiviral efficacy compared to the cellulose-based analogs when studied against human adenovirus- 5 and vesicular stomatitis virus. These findings for PAN-Por ${ }^{(+)}$suggest that the combined effects of a higher photosensitizer loading achievable from a non-covalent attachment strategy of the photosensitizer, coupled with a higher surface area from using nanofibers, together enable improved antimicrobial efficacy, likely from a higher amount of singlet oxygen produced per unit area, and leads us to conclude that future iterations of these photosensitizer-embedded materials should be designed with the goal of maximizing both surface area and photosensitizer loading. Although photobleaching was minimal over the duration tested, future studies aimed at prolonging the lifespan of materials operating by a photodynamic mode of action should be explored. Taken together, the combined antimicrobial results obtained for PAN-Por ${ }^{(+)}$demonstrate the promise and potential of scalable nanofiber-based aPDI materials as a platform technology for anti-infective materials: synthetic polyacrylonitrile nanofibers embedded with a cationic porphyrin photosensitizer exhibit superior antibacterial and antiviral efficacy compared to natural fiber materials, are less synthetically challenging to prepare than covalent strategies, are more easily scalable, and therefore have potential for incorporation into consumer staples that are broadly anti-infective. Future iterations and planned studies on next-generation materials will be focused on utilizing more cost-effective and commercially available photosensitizers that are capable of the rapid, efficient, and low-cost autonomous sterilization of a range of infective agents for the prevention of nosocomial infections in healthcare settings.

Supplementary Materials: The following are available online at http://www.mdpi.com/2079-4991/6/4/77/s1.

Acknowledgments: This research was supported in part by a North Carolina State University Research Innovation and Seed Funding (RISF) grant \#2014-0793. S.L.S. was supported by a NC State Department of Chemistry Wertz Undergraduate Research Fellowship.

Author Contributions: F.S., X.Z. and R.A.G. designed the research; X.S. synthesized the photosensitizer; J.Z. and Y.L. electrospun the PAN and PAN-Por ${ }^{(+)}$nanofibers and collected their SEM images; S.L.S., F.S. and R.A.G. performed the research and analyzed the data; S.L.S. and R.A.G. wrote the paper. All authors read, edited, and approved the final manuscript.

Conflicts of Interest: The authors declare no conflict of interest. 


\section{References}

1. Magill, S.S.; Edwards, J.R.; Bamberg, W.; Beldavs, Z.G.; Dumyati, G.; Kainer, M.A.; Lynfield, R.; Maloney, M.; McAllister-Hollod, L.; Nadle, J.; et al. Multistate point-prevalence survey of health care-associated infections. New Engl. J. Med. 2014, 370, 1198-1208. [CrossRef] [PubMed]

2. Jawad, A.; Snelling, A.M.; Heritage, J.; Hawkey, P.M. Exceptional desiccation tolerance of acinetobacter radioresistens. J. Hosp. Infect. 1998, 39, 235-240. [CrossRef]

3. Kramer, A.; Schwebke, I.; Kampf, G. How long do nosocomial pathogens persist on inanimate surfaces? A systematic review. BMC Infect. Dis. 2006, 6. [CrossRef] [PubMed]

4. Otter, J.A.; French, G.L. Survival of nosocomial bacteria and spores on surfaces and inactivation by hydrogen peroxide vapor. J. Clin. Microbiol. 2009, 47, 205-207. [CrossRef] [PubMed]

5. Otter, J.A.; Yezli, S.; Salkeld, J.A.G.; French, G.L. Evidence that contaminated surfaces contribute to the transmission of hospital pathogens and an overview of strategies to address contaminated surfaces in hospital settings. Am. J. Infect. Control 2013, 41, S6-S11. [CrossRef] [PubMed]

6. Neely, A.N.; Maley, M.P. Survival of enterococci and staphylococci on hospital fabrics and plastic. J. Clin. Microbiol. 2000, 38, 724-726. [PubMed]

7. Cimolai, N. Mrsa and the environment: Implications for comprehensive control measures. Eur. J. Clin. Microbiol. Infect. Dis. 2008, 27, 481-493. [CrossRef] [PubMed]

8. Nicolau, D.P. Current challenges in the management of the infected patient. Curr. Opin. Infect. Dis. 2011, 24 (Suppl. 1), S1-S10. [CrossRef] [PubMed]

9. Jain, A.; Duvvuri, L.S.; Farah, S.; Beyth, N.; Domb, A.J.; Khan, W. Antimicrobial polymers. Adv. Healthc. Mater. 2014, 3, 1969-1985. [CrossRef] [PubMed]

10. Noimark, S.; Dunnill, C.W.; Parkin, I.P. Shining light on materials-A self-sterilising revolution. Adv. Drug Del. Rev. 2013, 65, 570-580. [CrossRef] [PubMed]

11. Salwiczek, M.; Qu, Y.; Gardiner, J.; Strugnell, R.A.; Lithgow, T.; McLean, K.M.; Thissen, H. Emerging rules for effective antimicrobial coatings. Trends Biotechnol. 2014, 32, 82-90. [CrossRef] [PubMed]

12. Zhao, J.; Millians, W.; Tang, S.; Wu, T.; Zhu, L.; Ming, W. Self-stratified antimicrobial acrylic coatings via one-step UV curing. ACS Appl. Mater. Interfaces 2015, 7, 18467-18472. [CrossRef] [PubMed]

13. Floros, M.C.; Bortolatto, J.F.; Oliveira, O.B.; Salvador, S.L.; Narine, S.S. Antimicrobial activity of amphiphilic triazole-linked polymers derived from renewable sources. ACS Biomater. Sci. Eng. 2016, 2, 336-343. [CrossRef]

14. Kurt, P.; Wood, L.; Ohman, D.E.; Wynne, K.J. Highly effective contact antimicrobial surfaces via polymer surface modifiers. Langmuir 2007, 23, 4719-4723. [CrossRef] [PubMed]

15. Chen, L.; Bromberg, L.; Hatton, T.A.; Rutledge, G.C. Electrospun cellulose acetate fibers containing chlorhexidine as a bactericide. Polymer 2008, 49, 1266-1275. [CrossRef]

16. Bromberg, L.; Hatton, T.A. Poly(N-vinylguanidine): Characterization, and catalytic and bactericidal properties. Polymer 2007, 48, 7490-7498. [CrossRef]

17. Kenawy, E.-R.; Worley, S.D.; Broughton, R. The chemistry and applications of antimicrobial polymers: A state-of-the-art review. Biomacromolecules 2007, 8, 1359-1384. [CrossRef] [PubMed]

18. Paladini, F.; Pollini, M.; Sannino, A.; Ambrosio, L. Metal-based antibacterial substrates for biomedical applications. Biomacromolecules 2015, 16, 1873-1885. [CrossRef] [PubMed]

19. Li, Y.; Wei, S.; Wu, J.; Jasensky, J.; Xi, C.; Li, H.; Xu, Y.; Wang, Q.; Marsh, E.N.G.; Brooks, C.L.; et al. Effects of peptide immobilization sites on the structure and activity of surface-tethered antimicrobial peptides. J. Phys. Chem. C 2015, 119, 7146-7155. [CrossRef]

20. Demir, B.; Cerkez, I.; Worley, S.D.; Broughton, R.M.; Huang, T.-S. N-halamine-modified antimicrobial polypropylene nonwoven fabrics for use against airborne bacteria. ACS Appl. Mater. Interfaces 2015, 7, 1752-1757. [CrossRef] [PubMed]

21. Zhang, J.; Chen, Y.P.; Miller, K.P.; Ganewatta, M.S.; Bam, M.; Yan, Y.; Nagarkatti, M.; Decho, A.W.; Tang, C. Antimicrobial metallopolymers and their bioconjugates with conventional antibiotics against multidrug-resistant bacteria. J. Am. Chem. Soc. 2014, 136, 4873-4876. [CrossRef] [PubMed]

22. Dai, T.; Huang, Y.Y.; Hamblin, M.R. Photodynamic therapy for localized infections-State of the art. Photodiagn. Photodyn. Ther. 2009, 6, 170-188. [CrossRef] [PubMed]

23. Wainwright, M. In defence of 'dye therapy'. Int. J. Antimicrob. Agents 2014, 44, 26-29. [CrossRef] [PubMed] 
24. Wainwright, M. 'Safe' photoantimicrobials for skin and soft-tissue infections. Int. J. Antimicrob. Agents 2010, 36, 14-18. [CrossRef] [PubMed]

25. St Denis, T.G.; Dai, T.; Izikson, L.; Astrakas, C.; Anderson, R.R.; Hamblin, M.R.; Tegos, G.P. All you need is light: Antimicrobial photoinactivation as an evolving and emerging discovery strategy against infectious disease. Virulence 2011, 2, 509-520. [CrossRef] [PubMed]

26. Sharma, S.K.; Dai, T.H.; Hamblin, M.R. Antimicrobial photosensitizers: Harnessing the power of light to treat infections. In Antimicrobial drug discovery: Emerging strategies; Tegos, A., Mylonakis, E., Eds.; CABI: Wallingford, UK, 2012; pp. 310-322.

27. Maisch, T. A new strategy to destroy antibiotic resistant microorganisms: Antimicrobial photodynamic treatment. Mini Rev. Med. Chem. 2009, 9, 974-983. [CrossRef] [PubMed]

28. Huang, L.; Dai, T.; Hamblin, M.R. Antimicrobial photodynamic inactivation and photodynamic therapy for infections. Methods Mol. Biol. 2010, 635, 155-173. [PubMed]

29. Merkel, P.B.; Kearns, D.R. Radiationless decay of singlet molecular oxygen in solution. Experimental and theoretical study of electronic-to-vibrational energy transfer. J. Am. Chem. Soc. 1972, 94, 7244-7253. [CrossRef]

30. Henke, P.; Lang, K.; Kubat, P.; Sykora, J.; Slouf, M.; Mosinger, J. Polystyrene nanofiber materials modified with an externally bound porphyrin photosensitizer. ACS Appl. Mater. Interfaces 2013, 5, 3776-3783. [CrossRef] [PubMed]

31. Lhotakova, Y.; Plistil, L.; Moravkova, A.; Kubat, P.; Lang, K.; Forstova, J.; Mosinger, J. Virucidal nanofiber textiles based on photosensitized production of singlet oxygen. PLoS ONE 2012, 7. [CrossRef] [PubMed]

32. Jesenska, S.; Plistil, L.; Kubat, P.; Lang, K.; Brozova, L.; Popelka, S.; Szatmary, L.; Mosinger, J. Antibacterial nanofiber materials activated by light. J. Biomed. Mater. Res. A 2011, 99, 676-683. [CrossRef] [PubMed]

33. Mosinger, J.; Jirsak, O.; Kubat, P.; Lang, K.; Mosinger, B. Bactericidal nanofabrics based on photoproduction of singlet oxygen. J. Mater. Chem. 2007, 17, 164-166. [CrossRef]

34. Mosinger, J.; Lang, K.; Kubat, P.; Sykora, J.; Hof, M.; Plistil, L.; Mosinger, B., Jr. Photofunctional polyurethane nanofabrics doped by zinc tetraphenylporphyrin and zinc phthalocyanine photosensitizers. J. Fluoresc. 2009, 19, 705-713. [CrossRef] [PubMed]

35. Dolansky, J.; Henke, P.; Kubat, P.; Fraix, A.; Sortino, S.; Mosinger, J. Polystyrene nanofiber materials for visible-light-driven dual antibacterial action via simultaneous photogeneration of $\mathrm{NO}$ and $\mathrm{O}_{2}\left({ }^{1} \Delta_{\mathrm{g}}\right)$. ACS Appl. Mater. Interfaces 2015, 7, 22980-22989. [CrossRef] [PubMed]

36. Arenbergerova, M.; Arenberger, P.; Bednar, M.; Kubat, P.; Mosinger, J. Light-activated nanofibre textiles exert antibacterial effects in the setting of chronic wound healing. Exp. Dermatol. 2012, 21, 619-624. [CrossRef] [PubMed]

37. Feese, E.; Sadeghifar, H.; Gracz, H.S.; Argyropoulos, D.S.; Ghiladi, R.A. Photobactericidal porphyrin-cellulose nanocrystals: Synthesis, characterization, and antimicrobial properties. Biomacromolecules 2011, 12, 3528-3539. [CrossRef] [PubMed]

38. Carpenter, B.L.; Feese, E.; Sadeghifar, H.; Argyropoulos, D.S.; Ghiladi, R.A. Porphyrin-cellulose nanocrystals: A photobactericidal material that exhibits broad spectrum antimicrobial activity. Photochem. Photobiol. 2012, 88, 527-536. [CrossRef] [PubMed]

39. Carpenter, B.L.; Scholle, F.; Sadeghifar, H.; Francis, A.J.; Boltersdorf, J.; Weare, W.W.; Argyropoulos, D.S.; Maggard, P.A.; Ghiladi, R.A. Synthesis, characterization, and antimicrobial efficacy of photomicrobicidal cellulose paper. Biomacromolecules 2015, 16, 2482-2492. [CrossRef] [PubMed]

40. Bezman, S.A.; Burtis, P.A.; Izod, T.P.J.; Thayer, M.A. Photodynamic inactivation of E. Coli by rose bengal immobilized on polystyrene beads. Photochem. Photobiol. 1978, 28, 325-329. [CrossRef] [PubMed]

41. Drogat, N.; Granet, R.; Le Morvan, C.; Begaud-Grimaud, G.; Krausz, P.; Sol, V. Chlorin-pei-labeled cellulose nanocrystals: Synthesis, characterization and potential application in pdt. Bioorg. Med. Chem. Lett. 2012, 22, 3648-3652. [CrossRef] [PubMed]

42. Ringot, C.; Sol, V.; Barriere, M.; Saad, N.; Bressollier, P.; Granet, R.; Couleaud, P.; Frochot, C.; Krausz, P. Triazinyl porphyrin-based photoactive cotton fabrics: Preparation, characterization, and antibacterial activity. Biomacromolecules 2011, 12, 1716-1723. [CrossRef] [PubMed]

43. Ringot, C.; Saad, N.; Granet, R.; Bressollier, P.; Sol, V.; Krausz, P. Meso-functionalized aminoporphryins as efficient agents for photo-bactericidal surfaces. J. Porphyrins Phthalocyanines 2010, 14, 925-931. [CrossRef] 
44. Ringot, C.; Sol, V.; Granet, R.; Krausz, P. Porphyrin-grafted cellulose fabric: New photobactericidal material obtained by "click-chemistry" reaction. Mater. Lett. 2009, 63, 1889-1891. [CrossRef]

45. Dahl, T.A.; Robert Midden, W.; Hartman, P.E. Pure singlet oxygen cytotoxcity for bacteria. Photochem. Photobiol. 1987, 46, 345-352. [CrossRef] [PubMed]

46. Donnelly, R.F.; McCarron, P.A.; Tunney, M.M. Antifungal photodynamic therapy. Microbiol. Res. 2008, 163, 1-12. [CrossRef] [PubMed]

47. Tavares, A.; Carvalho, C.M.; Faustino, M.A.; Neves, M.G.; Tome, J.P.; Tome, A.C.; Cavaleiro, J.A.; Cunha, A.; Gomes, N.C.; Alves, E.; et al. Antimicrobial photodynamic therapy: Study of bacterial recovery viability and potential development of resistance after treatment. Mar. Drugs 2010, 8, 91-105. [CrossRef] [PubMed]

48. Caruso, E.; Banfi, S.; Barbieri, P.; Leva, B.; Orlandi, V.T. Synthesis and antibacterial activity of novel cationic bodipy photosensitizers. J. Photochem. Photobiol. B 2012, 114, 44-51. [CrossRef] [PubMed]

49. Muli, D.K.; Carpenter, B.L.; Mayukh, M.; Ghiladi, R.A.; McGrath, D.V. Dendritic near-ir absorbing zinc phthalocyanines for antimicrobial photodynamic therapy. Tetrahedron Lett. 2015, 56, 3541-3545. [CrossRef]

50. Carpenter, B.L.; Situ, X.; Scholle, F.; Bartelmess, J.; Weare, W.W.; Ghiladi, R.A. Antiviral, antifungal and antibacterial activities of a bodipy-based photosensitizer. Molecules 2015, 20, 10604-10621. [CrossRef] [PubMed]

51. Costa, L.; Faustino, M.A.; Neves, M.G.; Cunha, A.; Almeida, A. Photodynamic inactivation of mammalian viruses and bacteriophages. Viruses 2012, 4, 1034-1074. [CrossRef] [PubMed]

52. Smetana, Z.; Mendelson, E.; Manor, J.; van Lier, J.E.; Ben-Hur, E.; Salzberg, S.; Malik, Z. Photodynamic inactivation of herpes viruses with phthalocyanine derivatives. J. Photochem. Photobiol. B 1994, 22, 37-43. [CrossRef]

53. Gaspard, S.; Tempete, C.; Werner, G.H. Studies on photoinactivation by various phthalocyanines of a free or replicating non-enveloped virus. J. Photochem. Photobiol. B 1995, 31, 159-162. [CrossRef]

54. de Menezes, H.D.; Rodrigues, G.B.; Teixeira Sde, P.; Massola, N.S., Jr.; Bachmann, L.; Wainwright, M.; Braga, G.U. In vitro photodynamic inactivation of plant-pathogenic fungi colletotrichum acutatum and colletotrichum gloeosporioides with novel phenothiazinium photosensitizers. Appl. Environ. Microbiol. 2014, 80, 1623-1632. [CrossRef] [PubMed]

55. Dai, T.; Fuchs, B.B.; Coleman, J.J.; Prates, R.A.; Astrakas, C.; St Denis, T.G.; Ribeiro, M.S.; Mylonakis, E.; Hamblin, M.R.; Tegos, G.P. Concepts and principles of photodynamic therapy as an alternative antifungal discovery platform. Front. Microbiol. 2012, 3. [CrossRef] [PubMed]

56. Frimannsson, D.O.; Grossi, M.; Murtagh, J.; Paradisi, F.; O'Shea, D.F. Light induced antimicrobial properties of a brominated boron difluoride $\left(\mathrm{BF}_{2}\right)$ chelated tetraarylazadipyrromethene photosensitizer. J. Med. Chem. 2010, 53, 7337-7343. [CrossRef] [PubMed]

57. Grellier, P.; Santus, R.; Mouray, E.; Agmon, V.; Maziere, J.-C.; Rigomier, D.; Dagan, A.; Gatt, S.; Schrevel, J. Photosensitized inactivation of plasmodium falciparum- and babesia divergens-infected erythrocytes in whole blood by lipophilic pheophorbide derivatives. Vox Sang. 1997, 72, 211-220. [CrossRef] [PubMed]

58. Jori, G.; Fabris, C.; Soncin, M.; Ferro, S.; Coppellotti, O.; Dei, D.; Fantetti, L.; Chiti, G.; Roncucci, G. Photodynamic therapy in the treatment of microbial infections: Basic principles and perspective applications. Lasers Surg. Med. 2006, 38, 468-481. [CrossRef] [PubMed]

59. Feese, E. Development of novel photosensitizers for photodynamic inactivation of bacteria. Ph.D. Thesis, North Carolina State University, Raleigh, NC, USA, 2011.

60. Boucher, H.W.; Talbot, G.H.; Bradley, J.S.; Edwards, J.E.; Gilbert, D.; Rice, L.B.; Scheld, M.; Spellberg, B.; Bartlett, J. Bad bugs, no drugs: No ESKAPE! An update from the infectious diseases society of america. Clin. Infect. Dis. 2009, 48, 1-12. [CrossRef] [PubMed]

61. Feese, E.; Ghiladi, R.A. Highly efficient in vitro photodynamic inactivation of Mycobacterium smegmatis. J. Antimicrob. Chemother. 2009, 64, 782-785. [CrossRef] [PubMed]

62. Sperandio, F.F.; Huang, Y.-Y.; Hamblin, M.R. Antimicrobial photodynamic therapy to kill gram-negative bacteria. Recent Pat. Antiinfect. Drug Discov. 2013, 8, 108-120. [CrossRef] [PubMed]

63. Chinga-Carrasco, G. Cellulose fibres, nanofibrils and microfibrils: The morphological sequence of $\mathrm{mfc}$ components from a plant physiology and fibre technology point of view. Nanoscale Res. Lett. 2011, 6, 1-7. [CrossRef] [PubMed] 
64. Ke, M.-R.; Eastel, J.M.; Ngai, K.L.K.; Cheung, Y.-Y.; Chan, P.K.S.; Hui, M.; Ng, D.K.P.; Lo, P.-C. Photodynamic inactivation of bacteria and viruses using two monosubstituted zinc(II) phthalocyanines. Eur. J. Med. Chem. 2014, 84, 278-283. [CrossRef] [PubMed]

65. Sobotta, L.; Skupin-Mrugalska, P.; Mielcarek, J.; Goslinski, T.; Balzarini, J. Photosensitizers mediated photodynamic inactivation against virus particles. Mini-Rev. Med. Chem. 2015, 15, 503-521. [CrossRef] [PubMed]

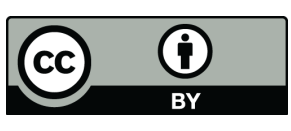

(C) 2016 by the authors; licensee MDPI, Basel, Switzerland. This article is an open access article distributed under the terms and conditions of the Creative Commons Attribution (CC-BY) license (http://creativecommons.org/licenses/by/4.0/). 